\title{
Irish Immigration To America: An Analysis of The Social And Economic Issues Irish Immigrants Experienced As Conveyed Through Toibin's Book Brooklyn
}

\author{
Fatimah Alzughaibi ${ }^{1}$ \\ Graduate Student, Department of English, UMSL University, St. Louis, United States.
}

\begin{abstract}
This paper will analyze the social and economic situations Irish immigrants found themselves in once they reached America using Toibin's book Brooklyn as an example. Through carefully exploring the themes and topics presented in the book, and comparing them with actual historical records, a larger picture of Irish immigration in America appears that tells the tale of the lives and struggles of this people group.
\end{abstract}

Keywords: Irish, Immigration, immigrants, Toibin, America, Eilis.

\section{INTRODUCTION}

Irish immigration to the United States started to gain popularity during the middle portion of the $19^{\text {th }}$ century and was prevalent up and to the 1970s (Daniels 17-18). This great influx of immigrants found a response to economic hardships Irish people faced in their home country. Between 1845 and 1850, Ireland experienced an extreme famine brought on by a devastating fungus that attacked and ultimately destroyed the country's many potato crops. The destruction of this resource brought on starvation and related diseases. While scholars disagree as to how many people died as a consequence of this famine and epidemic, some estimate the number to be close to one million. In reaction, a million or more Irish people emigrated from about 1845 to 1855 , and at least 500,000 relocated to the United States (Brennan 4-5). While the Irish Potato Famine receded after the 1850s, the long lasting repercussions of the famine continued to provoke Irish emigration into the latter part of the $20^{\text {th }}$ century. Between the years of 1820 and 1975, an estimated 4.7 million Irish people came to the United States (Brennan 6). Today, there are around 32 million Americans, or roughly 12 percent of the population, that are of Irish ancestry. These individuals' ancestors came to America to embark on a new life, escape the social, economic, and political turmoil in their motherland, and provide their families with better opportunities. The phenomenon of Irish immigration in America is complex and situations varied for immigrants based on their religious convictions, the time period in which they immigrated, and their economic status. However, by and large, Irish immigration to America was marked by overall poor treatment, poverty, and injustice ("Irish American Journey: Irish Immigration to America: How America Became Irish").

\section{TOIBIN's PORTRAYAL OF THE SOCIAL CHALLENGES IRISH IMMIGRANTS FACED}

Toibin highlights the cultural and social struggles Irish immigrants faced in America, as well as the ways in which they mitigated these inconveniences, forged a life for themselves, and build meaningful communities and social circles, many of which still survive today. These social connections were pivotal to helping Irish migrants obtain the paperwork necessary to come to America. Furthermore, they provided the new arrivals with a social network once they landed in the United States ("Irish American Journey: Irish Immigration to America: How America Became Irish."). In the book, Toibin describes Eilis Lacey's sponsors as being her sister Rose and Father Flood. Toibin writes, "Father Flood wrote a formal letter sponsoring Eilis and guaranteeing to take care of her accommodations as well as her general and financial welfare..." (Toibin 27). Additionally, Toibin states that Rose played an essential role in helping her sister obtain the visa necessary to go to the United States and states:

Rose had organized everything, even managing to befriend by telephone a figure in the American Embassy in Dublin who sent the necessary forms and a list of doctors authorized to write a report on Eilis's general health, and a list of other things the Embassy would require, including a precise offer of work... a guarantee that she would be looked after financially on her arrival and a number of character references (Toibin 27).

\footnotetext{
${ }^{1}$ Corresponding Author: FA1512@hotmail.com
} 
The experience of Eilis was not unique; in fact, all Irish immigrants who wanted to come to America during most of the $20^{\text {th }}$ century had to furnish the Embassy with appropriate paperwork prior to obtaining a visa and passport. The required documents and testimonies were aimed at ensuring that the individual planning to move to the United States would not bring illness and disease into the country. Also, economic provisions had to be in place to make certain that the new arrival would be able to support themselves and not become a burden on the state. Finally, character references helped to ensure that the prospective immigrant was not a criminal or prone to nefarious conduct (Daniels 62). Therefore, it was almost impossible for Irish people to immigrate to the United States unless they were independently wealthy or had an already established social circle, made up of friends and family, living in America that could financially support them and help them to procure employment and housing. This helped to create tight-knit, Irish communities in America because, for the most part, Irish immigrants tended to live with other Irish immigrants and form communities alongside their fellow countrymen and women.

Toibin's narrative has Eilis living in an immigrant community, made up mostly of Irish people, in New York City. To reach her new home, Eilis must endure a long and arduous boat ride from Dublin to New York. Like millions of immigrants before her, Eilis was traveling from one world to the next. Once her boat docks in New York, she is taken to a boarding house in Brooklyn - which was already arranged by Father Flood - that is run by a woman named Mrs. Kehoe. At the boarding house there are many young immigrant women, most of which are of Irish decent. Toibin identifies one resident as "Miss McAdam from Belfast, who worked as a secretary" (57). Another Irish resident is Patty McGuire. Unlike the other women, Patty was born in New York but had parents from Ireland (Toibin 58). In sum, the girls who resided in this house were mostly of Irish decent and represented both immigrants and first generation Americans. This is an accurate description of what the demographics of boarding houses in New York really would have been like.

This aspect of the novel highlights another phenomenon associated with Irish immigration to America - namely the small, tight-knit communities that sprung up in the Northeast, predominately in large cities such as New York and Boston. These two cities were heavily settled by Irish immigrants and an estimated two-thirds of all Irish immigrants to the United States settled in the Northeast corridor between Boston and Philadelphia. This was due, in part, to the travel passage. Most boats from Ireland docked in New York and, due to the proximity of other large cities, the Irish immigrants tended to stay in these areas. Furthermore, the type of work most Irish men and women engaged in was suitable for city life. They had minimal skills and mostly found employment as domestic servants, factory workers, and white-collar jobs such as secretaries, nurses, and teachers. Many others joined the monastic orders and served their communities as nuns or clergy ("Irish - Adaptation and Assimilation - Immigration"). Since there were many more Catholic churches and convents in cities, the Irish immigrants tended not to venture into the countryside. As a result of these two influencing factors, small Irish communities were formed alongside other immigrant communities, made up primarily of the poorest sectors of society and located in the most marginalized parts of the city. These communities, for the most part, retained their native traditions, beliefs, languages, and cultures. The Irish communities, in particular, kept many of their homeland traditions to include their strong Catholic beliefs and worldviews (Hara 33).

Yet another Irish immigration theme stressed in Toibin's book is the ways in which immigrants, in general, were isolated from mainstream society due to overarching stereotypes and systematic discrimination. Throughout the novel, Eilis and other immigrants encounter various forms of discrimination either directly or indirectly. Toibin describes immigrant's having their children taken from them by the federal government on a fairly regular basis for rather trivial matters. He writes:

She [Eilis] remember now how much the neighbors had dreaded the day when the court sat, not because of the cases that were reported in the papers of petty theft, or drunkenness, or disorderly conduct, but because sometimes the court ordered children to be taken into their care, put into orphanages or industrial schools or foster homes because they mitched from school or caused trouble or because of problems with their parents. Sometimes, inconsolable mothers could be found screaming, howling outside the courthouse as their children were taken away (Toibin 70).

This is, perhaps, the most blatant form of discrimination witnessed in the book; however, it is not the only one. Rather, Eilis encounters discrimination in many forms - against Italians, blacks, Jews, and lower-class Irish.

The experiences depicted by Toibin can be substantiated by historians and were, in fact, common occurrences in migrant communities. Children were oftentimes taken from parents and forced to attend state sponsored boarding schools or sent to the factories to work as basically indentured servants. Those sent to factories were placed in situations similar to old workhouses where they worked, oftentimes, six or seven days a week for 12 hours a day. In 
turn, they received basic food and a roof over their head (Diner 84). The overarching mindset was that migrant children had to be assimilated into American society and this could best be accomplished by taking them from their parents and placing them in either established American households or institutional settings (Diner 88). This phenomenon was witnessed oftentimes in the Irish community because Irish households tended to have more children than some other nationalities and, oftentimes, the immigrants themselves were children who were sent abroad to procure work (Diner 88).

Systematic discrimination, too, was experienced by nearly all immigrants who arrived in America, but some groups had it worse than others. The Irish were ostracized from American society for many reasons, to include their Catholic beliefs. Protestant Americans, who made up most of the population, were very skeptical of Catholicism and its seemingly strange beliefs and values. For instance, the prayer beads, veneration of Saints, statues, and respect for Mary were all considered problematic and cause for concern because they were a direct violation of Protestant theology ("Irish American Journey: Irish Immigration to America: How America Became Irish.").

Mobs, too, resulted, at times, in reaction to the strong dislike many people held for Catholics. For instance, in Boston, a mob of Protestant workmen burned down a Catholic Church and convent to protest Irishmen supposedly taking their jobs. Mob attacks and violence were not unusual occurrences and many Catholics and Catholic institutes were destroyed, primarily in cities, throughout the $19^{\text {th }}$ and even into the $20^{\text {th }}$ century ("Irish American Journey: Irish Immigration to America: How America Became Irish."). This dislike of Catholicism is highlighted in Toibin's book. A great instance of this is seen when Eilis marries Tony, an Italian plumber, in part because they are both Catholic. Due their religious beliefs, they were basically shunned from the rest of society and could not even consider marrying someone from a Protestant family. Tony deeply loves her and, eventually, she comes to appreciate him. Together, they are able to share in some of the trials associated with being minorities in America. They endure these struggles together and provide emotional, as well as financial, support for one another. Together, they are able to augment their living situation and increase their quality of life. With two incomes, instead of just one, their economic situation improves and they have a real chance of making a decent life for themselves. It is somewhat shocking; therefore, that Eilis still longs to return to Ireland. This may highlight some of the undertones of her relationship with Tony. Perhaps, this is a marriage based on mutual necessity and not love. Undoubtedly, many migrants found themselves marrying for economic stability and not for romantic purposes. It is just one more unpleasant consequence of being a member of a marginalized group.

Additionally, Irish were labeled as angry, troublemaking alcoholics who wanted to cause a ruckus and wreak havoc. For instance, many terms and phrases, such as "fighting Irish," "as drunk as an Irishman," and "don't get your Irish up," came into the English language in response to these unfavorable stereotypes. One-writer states:

The Irish were depicted as illiterate, greedy,--therefore desperate to make it "Micks on the Make"--their families were too clannish, bred like rabbits, and the Irish were entirely figured to be a stupid servant race by the Bostonians and most of "native" America. These images were portrayed in the daily Boston and New York newspapers, photographs, and other media of the time (Hara 21).

In sum, immigrants in general and Irish immigrants in particular faced a series of social stigmas and stereotypes when they arrived in the United States. Toibin does an adequate job demonstrating how Irish people were treated and the myriad of ways they were systematically discriminated against and forced to endure unfair and unjust treatment. Additionally, Toibin highlights the importance of the strong, tight-knit, ethnic-based Irish communities that sprung up in New York City. His portrayal seems, according to the historical record, to be fairly accurate and not farfetched. It is even reasonable to assume that Eilis, an Irish Catholic girl, would marry an Italian Catholic. In general, the book justly portrays some of the social issues Irish immigrants faced in America.

\section{Toibin's Portrayal of The ECONOMic ChallengeS IRISH IMMIGRANTS FACED}

While social and economic realities mostly go hand-in-hand, there is merit in trying to separate the two for analytical purposes. Recognizing the overlap, this portion of the paper will focus on the economic challenges Irish people in American experienced according to Toibin, and then compare the author's description to historical facts and statistics. The first economic issue touched upon by Toibin was the overall poverty Irish people faced in their home country and its influence on immigration to America. The whole reason why Rose introduces Eilis to Father Flood - during his visit from New York back home to Ireland - is so that her sister might make the connections necessary to travel to America and procure employment. Father Flood highlights the myriad of opportunities, which include work and education. Eilis, unable to find employment in Ireland, backs her bags and ventures to America. 
This element of Irish immigration to America is well attested to by scholarly sources. Nearly all of the many Irish immigrants came to America specifically due to the poor economic situation in Ireland. As already stated, the Potato Famine was an initial factor in large-scale immigration, but even once this economic stress was alleviated, its repercussions were long-lasting and caused a great deal of economic instability for decades ("Irish American Journey: Irish Immigration to America: How America Became Irish."). Additionally, one analyst notes that "Ireland did not share in the postwar boom enjoyed by most other Western economies; growth was sluggish and unemployment high. Consequently, over 400,000 people left Ireland in the 1950s to find work elsewhere" (Lee 6). Men and women, alike, were unable to find employment and, according to some scholars, at times unemployment rates were as high as 60-70 percent of the adult population (Brennan 12). Due to this harsh reality, people were literally starving to death. Some experts estimate the infant mortality rate to be as high as 50 percent at times (Brennan 13). This was primarily a result of food shortages and related diseases. This bleak situation promoted widespread immigration to the United States as well as many other nations. In sum, the economic situation in Ireland was nothing short of dismal and, while work in the United States was hard, grueling, and underpaid, it was considered an improvement.

Not only does Toibin shed light on the work incentive that drove millions of Irish people to migrate to America, he also correctly portrays the types of work they did when arrived (Daniels 47). Irish people, by and large, were not interested in free land grabs being offered to those who settled in the West. As one literary critic points out "They had already been failed once by the land" (Daniels 88). It is not hard to see why they would be leery to engage in agricultural work and homesteading. After watching millions of their countrymen and women die due to famine, a more stable means of earning a living was sought after. In the book, Father Flood comes to the United States to serve as a clergyman. Also, Eilis and many other Irish women find employment in a department store. Miss McAdam from Belfast, worked as a secretary (Young). These are all examples of occupations that Irish immigrants would have had during this time. Toibin does an excellent job of placing his characters into appropriate jobs and roles (Young).

Historical evidence substantiates Toibin's portrayal of Irish workers in America. While prior to the 1800s, many Irish immigrants became farmers in America; this trend did not last long. In fact, after 1840, nearly all-Irish immigrants went directly to the cities and sought jobs in urban areas (Stoddard 151-153). Men tended to work in the railroad industry, or were contracted to build streets, canals, sewers, and other types of buildings and infrastructure. Still others worked in mills and factories. Irish women, on the other hand, sought jobs as maids and servants in private households and public buildings, such as hotels and government edifices. Women, too, worked in mills, factories, department stores, and office buildings. By the 1900s, many women served in nursing and teaching capacities, which were considered better employment opportunities and typically paid higher wages than mill and factory work ("Irish American Journey: Irish Immigration to America: How America Became Irish.").

Additionally, many Irish men and women found stability and security in the monastic orders. Poor and destitute Irish men sought refuge in the priesthood, and a large number of women joined one of the many local nunneries. While Catholic monastic life was not luxurious and was characterized by hard work and austerity, at least meals and lodging were provided as well as a decent level of medical care. Many single men and women found this to be a viable option in light of their dismal circumstances and a relief from the pressures of life outside of the protection of the Church ("Irish American Journey: Irish Immigration to America: How America Became Irish.").

Probably, the aspect of the book Toibin details most thoroughly is the unique experience Irish women immigrants had in America. In Ireland, women had little opportunity to either procure employment or obtain an education. In America, this was not the case, especially in the 1940s and 1950s. The women characters in Toibin's book all have jobs and are able to find employment in America without much trouble. These jobs, while not high paying, are not overly taxing and mostly white collar. Additionally, these women are able to take classes and augment their education and skillset. Eilis, for instance, takes classes in bookkeeping in addition to working at the department store. Other females, too, are able to balance work and school, which suggests that there is the option of upward mobility. Furthermore, it is interesting that Eilis and many of her female companions immigrate to America on their own. They did not come with their husbands or families like most female immigrants to America did. Instead, they set out, on their own, to better their situations in life. This made their situation somewhat rare and distinct from most other female immigrants.

History substantiates Toibin's portrayal of Irish women immigrants to America. In traditional Irish households, men were still regarded as the head, but women were also awarded a great deal of power and say, especially in comparison to other contemporary societies. For instance, most of the time, it was the women who handled the monetary affairs and made the financial decisions ("Irish American Journey: Irish Immigration to America: How 
America Became Irish."). Some women even worked in larger cities, such as Dublin, and spend long durations of time away from their husbands and families. This meant that the culture, as a whole, saw women as more independent than most other European cultures at the time.

This is not to suggest that Ireland was a feminist utopia. While women were granted limited freedom and recognized for their contributions to the family, daughters were mostly seen as less valuable than sons, in part because they garnished, on average, lower wages. Mostly, their contributions to the family were not even enough to cover their own expenses, let alone add to the family's wealth. Therefore, families were eager to marry their daughters off or send them to other nations, to include the United States, for employment ("Irish American Journey: Irish Immigration to America: How America Became Irish.").

As the economic situation in Ireland continued to deteriorate, families would save money to pay for their daughters' passages to America or other nations where economic opportunities were more promising. While the initial financial burden was substantial, in the long run the family was fiscally better off. It meant one less mouth to feed, body to cloth, and care to provide. Daughters oftentimes viewed this opportunity as a positive one because there were ample jobs in America and a degree of freedom that was not possible in Ireland. There, they would be able to obtain some degree of independence and possibly even obtain a limited education. In other words, in America they could obtain a status that would be impossible to achieve in Ireland. It was employment, and not marriage, that continued to be women's priority even once they settled in the United States. This resulted in Irish women outnumbering Irish men in America (Brennan 39).

In short, the economic situations in Ireland prompted many marginalized and struggling citizens to migrate to the United States and other, more prosperous, nations. These economic hardships were caused by the long-lasting economic struggles associated with the Potato Famine and the lack of economic rejuvenation Ireland experienced after WWII. Remarkably, there were more women who migrated to the United States than men. This created a unique experience for Irish women, and created a situation where many Irish women achieved a level of independence beyond what was typical at the time. Women worked in many capacities but, in the $20^{\text {th }}$ century, they mostly procured employment in white-collar jobs.

\section{INCONCLUSION}

In conclusion, Toibin does an excellent job of shedding light on the many social and economic challenges and obstacles Irish immigrants to America faced throughout the decades. His book demonstrates that the main social challenges this group of faced were based on discrimination due to preexisting stereotypes and their strong Catholic faith. This resulted in isolation from society and unfair treatment. On the other hand, the main economic challenges Irish immigrants faced were: sub-standard housing, poor treatment in the workplace, and low paying jobs. Therefore, a large percentage jointed the monastic order and stayed single to better their economic situations. Through centering his book on female characters, the author is able to successfully establish the unique experiences of Irish female immigrants. They made up a large percentage of immigrants and came to the United States not as appendages to their husbands, but as independent people wanting to further their careers and education. This phenomena was unprecedented since women, typically, did not venture to America on their own. In general, Toibin was able to highlight all of these realities through detailing the lives of the characters in his book and demonstrating how social and economic realities played out in the narrative.

\section{REFERENCES}

[1] Brennan, Margaret. The Irish Bridget: Irish Immigrant Women in Domestic Service in America,

[2] 1840-1930. Syracuse, N.Y.: Syracuse University Press, 2009. Print.

[3] Daniels, Roger. Coming to America: A History of Immigration and Ethnicity in American Life.

[4] New York, NY: HarperCollins, 1990. Print.

[5] Diner, Hasia R. Erin's Daughter in America: Irish Immigrant Women in the Nineteenth Century.

[6] London: Johns Hopkins U.P., 1983. Print.

[7] Diner, Hassia. Irish Immigration and Women's Unique Experiences. Baltimore: Johns Hopkins

[8] Press, 1985. Print.

[9] Hara, Megan. Irish Immigrants, 1840-1920. Mankato, Minn.: Blue Earth Books, 2002. Print.

[10] "Irish - Adaptation and Assimilation - Immigration...- Classroom Presentation | Teacher

[11] Resources - Library of Congress." Irish - Adaptation and Assimilation - Immigration- 
American Research Journal of English and Literature, Volume 1, Issue 6, 2015

ISSN 2378-9026

[12] Classroom Presentation | Teacher Resources - Library of Congress. Web. 4 Nov. 2014.

[13] "Irish American Journey: Irish Immigration to America: How America Became Irish." Irish

[14] American Journey: Irish Immigration to America: How America Became Irish. Web. 4

[15] Nov. 2014.

[16] Lee, Virginia. "Brooklyn." In Text Guide. Print.

[17] Stoddard, Eve Walsh. "Home and Belonging amongst Irish Migrants: Transnational verses Place

[18] Identities in The Light of Evening and Brooklyn: A Novel.” Eire-Ireland. 47.2 (2012):

[19] 147-171. Print.

[20] Toibin, Colm. Brooklyn: A Novel. New York: Scribner, 2009. Print.

[21] Young, Troy. "Brooklyn as the "Untold Story" of "Eveline": Reading Joyce and Toibin with

[22] Ricoeur. Journal of Modern Literature 37.2 (2014): 123-140. Print. 